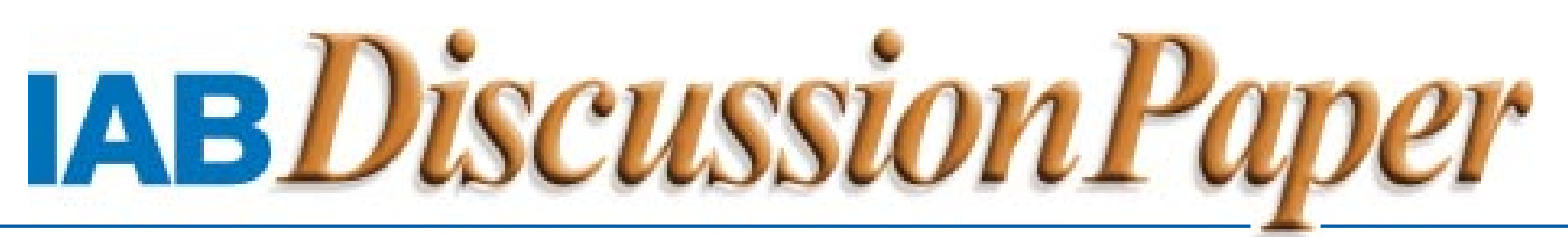

Beiträge zum wissenschaftlichen Dialog aus dem Institut für Arbeitsmarkt- und Berufsforschung

No. $4 / 2004$

\title{
Do newly founded firms pay lower wages? \\ First evidence from Germany
}

Udo Brixy, Susanne Kohaut and Claus Schnabel 


\title{
Do newly founded firms pay lower wages? First evidence from Germany
}

\author{
Udo Brixy, Susanne Kohaut and Claus Schnabel
}

Auch mit seiner neuen Reihe „IAB-Discussion Paper“ will das Forschungsinstitut der Bundesagentur für Arbeit den Dialog mit der externen Wissenschaft intensivieren. Durch die rasche Verbreitung von Forschungsergebnissen über das Internet soll noch vor Drucklegung Kritik angeregt und Qualität gesichert werden.

Also with its new series "IAB Discussion Paper" the research institute of the German Federal Employment Agency wants to intensify dialogue with external science. By the rapid spreading of research results via Internet still before printing criticism shall be stimulated a quality shall be ensured. 


\title{
Do newly founded firms pay lower wages?
}

\section{First evidence from Germany}

\author{
Udo Brixy ${ }^{1}$, Susanne Kohaut ${ }^{\text {D }}$ and Claus Schnabel ${ }^{\text {B }}$
}

\begin{abstract}
Using a linked employer-employee data set for Germany, this paper analyses wage setting in a cohort of newly founded and other establishments from 1997 to 2001. While theory provides alternative explanations for higher or lower wages in newly founded firms, we show empirically that start-ups tend to pay lower wages, ceteris paribus. On average, wages in newly founded establishments are 8 percent lower than in similar incumbent firms. This negative wage differential is substantially smaller in eastern than in western Germany. The wage differential is shown to decline over time as the newly founded firms become more mature.
\end{abstract}

\section{Zusammenfassung}

Unter Verwendung eines kombinierten Firmen-Beschäftigten-Datensatzes für Deutschland analysiert dieser Beitrag die Lohnsetzung in einer Kohorte von neu gegründeten und anderen Betrieben im Zeitraum von 1997 bis 2001. Während theoretische Erklärungsansätze verschiedene Begründungen für höhere oder niedrigere Löhne in neu gegründeten Betrieben liefern, zeigen wir empirisch, dass Neugründungen ceteris paribus tendenziell niedrigere Löhne zahlen. Im Durchschnitt liegen die Löhne in Neugründungen 8 Prozent unter denen in vergleichbaren bestehenden Betrie-

* The authors would like to thank the Deutsche Forschungsgemeinschaft for financial support under project SCHN-730/2-1 and Joachim Wagner and Markus Heckmann for helpful comments and suggestions.

1 Dr. Udo Brixy, Institut für Arbeitsmarkt- und Berufsforschung der Bundesanstalt für Arbeit, Regensburger Straße 104, D-90478 Nürnberg, Udo.Brixy@iab.de.

2 Dr. Susanne Kohaut, Institut für Arbeitsmarkt- und Berufsforschung der Bundesanstalt für Arbeit, Regensburger Straße 104, D-90478 Nürnberg, Susanne.Kohaut@iab.de.

3 Prof. Dr. Claus Schnabel, Friedrich-Alexander-Universität Erlangen-Nürnberg, Lehrstuhl für Arbeitsmarkt- und Regionalpolitik, Lange Gasse 20, D-90403 Nürnberg, claus.schnabel@wiso.uni-erlangen.de. 
ben. Dieses negative Lohndifferenzial fällt in Ostdeutschland deutlich geringer aus als in Westdeutschland. Es zeigt sich, dass mit der Reifung der Betriebe im Zeitablauf das Lohndifferenzial zurückgeht.

Nürnberg, Juli 2004

Keywords: Wages, newly founded firms, linked employer-employee data, Germany

JEL-classification: D21, J30 


\section{Introduction}

In recent years, newly founded firms (or business start-ups) have increasingly received attention by academics as well as by economic policy. Quite a few studies have been published that analyze the success of newly founded firms over the years in terms of survival rates, employment growth, sales growth and other indicators of firm performance (see, e.g., Dunne et al. 1989 for the US, Storey 1994 for the UK, and Brüderl et al. 1996 for Germany). Due to high and persistent unemployment, in Germany a special focus has been on the employment effects of new firms (see, e.g., Wagner 1994, Brixy and Kohaut 1999, Almus 2002), and economic policy strongly stimulates the founding of new firms in order to improve the dismal labour market situation.

Interestingly, the level and development of wages in newly founded firms have received little attention so far although they provide interesting information on the performance of new firms and on the quality of the jobs provided. Newly founded firms are usually equated with small firms, and for these we know that they tend to pay lower wages, ceteris paribus ( $\mathrm{Oi}$ and Idson 1999). We do not know in detail, however, whether newly founded firms pay higher or lower wages than incumbent firms of the same size. We also do not know whether such a wage differential - if it exists - vanishes over time once the new business matures and how fast such a convergence in wages takes place (i.e. how long it takes until a new firm becomes an incumbent firm).

This paper seeks to overcome this research deficit by analyzing the wage differential between newly founded and other firms in Germany in the period 1997 to 2001. It makes use of a representative sample of establishments that were founded in 1995/96 and that form part of a large-scale set of establishment data in Germany. After a brief discussion of the main hypotheses and the extant evidence in section 2, this unique data set is described in section 3. Econometric wage analyses are conducted in Section 4, and the identified wage differential of the cohort of newly founded establishments is traced over time. Section 5 provides some concluding remarks and suggestions for future research. 


\section{Wages in small, in young and in newly founded firms}

There are several reasons why wages in newly founded firms may differ from those in incumbent firms (for a general discussion of the firm age and wages nexus see Brown and Medoff 2003). They imply alternative hypotheses on the direction and the persistence of this wage differential. In the following, some considerations suggesting higher wages in newly founded firms are presented first and are then contrasted by several arguments for a negative wage differential. This theoretical reasoning will be supplemented by a brief look at the related empirical evidence.

Since newly founded firms, by definition, have no current employees and cannot fill vacancies through training and promotion in internal labour markets, they need to attract employees from the external labour market. Potential employees will compare the compensation and working conditions offered with what they receive from their current employers (or with

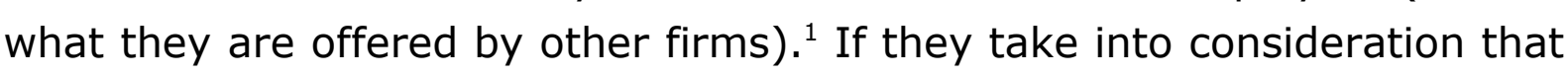
newly founded firms are much more likely to expire than older ones, they can be expected to demand higher wages in the sense of a wage differential compensating for the increased risk of a job loss. Wage demands will also be higher if potential employees recognize that newly founded firms offer fewer fringe benefits (such as pension plans) than long-established firms. With a falling risk of failure (and an increase in fringe benefits) over time, the size of this compensating wage differential can be expected to fall (unless there is a sort of ratchet effect that makes employees stick to their relative starting wages).

In contrast, wages in newly founded firms may be lower than in incumbent firms because of their lower ability to pay. Most new firms operate at such a small scale of output that they are confronted with an inherent cost disadvantage and thus need to pursue a strategy of compensating factor differentials which includes paying lower wages (Audretsch et al. 2001). Put more general, in the start-up phase of a business it is essential for sur-

1 Lewin and Mitchell $(1995,33$ f.) thus stress that the human resource strategy of a start-up business should focus most strongly on selection/sourcing and on compensation and reward systems (which may include equity participation of employees in start-ups). 
vival to keep labour costs as low as possible, and any claim of inability to pay higher wages is much more credible (and more likely to be accepted by the employees) when made by a newly founded firm than by a longsurviving firm. In this case, the new firm may not be able to poach employees from other firms but may rely more on attracting workers who are currently unemployed or out of the labour force. This selection and the lower wages offered do not necessarily imply that these employees are less qualified, since newly founded firms do not have to pay the wage premiums for tenure and firm-specific knowledge which employees in incumbent firms command. ${ }^{\text {O }}$ Over time, this negative wage differential should become smaller since a firm's ability to pay can be expected to rise and since its employees acquire tenure and valuable firm-specific human capital.

These contrasting theoretical hypotheses suggest that an empirical investigation may be worthwhile. To the best of our knowledge, however, no empirical studies seem to exist that have explicitly addressed these issues with German or international data on newly founded firms. To be sure, there is a vast literature demonstrating that small firms pay lower wages for reasons that are not always perfectly well understood (standard references include Brown et al. 1990 and Oi and Idson 1999; for Germany, see Schmidt 1995 and Wagner 1997). Since newly founded firms are usually small, it is fairly save to conclude that they also pay low wages, but it remains an open question whether they pay higher or lower wages than incumbent firms of the same size.

There is also an emerging literature (consisting of not more than four econometric studies up to now) that tries to find out whether the age of a firm has an influence on the wages paid to its employees and that provides some information on the wage differential of young firms. With Dutch firm data, Audretsch et al. (2001) identify a positive impact of firm age on productivity and wages, even after controlling for the size of the

2 There also may exist non-monetary incentives that help newly founded firms to hire employees in spite of lower wages. These include enthusiasm for the business idea and the attractiveness of a situation with flat hierarchies where structures can still be formed. Some employees could also speculate that they are first in line and therefore in a good position for a career within the firm. 
firm. For the U.S., Brown and Medoff (2003) find that firms which have been in business longer pay higher wages, but tend to pay lower wages after controlling for worker characteristics. Similar results are obtained for western Germany by Kölling et al. (2002) who state that, if anything, younger firms seem to pay more ceteris paribus. Heyman (2004) investigates the employer age-wage effect in Sweden and finds considerable heterogeneity across years, along segments of the firm age distribution,

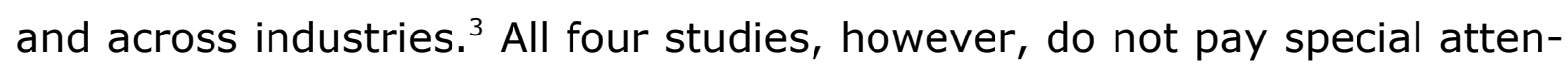
tion to newly founded firms and do not follow an age cohort of firms over time. Such a line of investigation will be pursued now.

\section{The data}

The data used in this study is derived from two sources that are closely interrelated and together form an employer-employee data set. The employee side of the data set is the "German Employment Statistics" (sometimes also called the "German Social Insurance Statistics"). It requires all public and private employers to report certain information about every employee who is subject to obligatory social insurance, i.e. health and unemployment insurance along with pension funds. Misreporting is legally sanctioned. The information collected is transformed into an establishment file that provides longitudinal information about the establishments and their employees and which is called "IAB Establishment Register". ${ }_{\mathrm{A}}$ great advantage of this database is that it covers all establishments that employ at last one employee who is liable to social insurance. The attributes of each firm covered in this database are the number of employees, their sex, age, and qualification (four levels) as well as the wages and salaries paid and the exact duration of the engagement in days. Although these data refer to individuals, only aggregate data at establishment level were available to us.

3 A different line of investigation is pursued by Brüderl et al. (1996: $101 \mathrm{f}$ ) who investigate how long it takes the founder of a firm to reach the personal income he or she received in previous employment.

4 IAB is an acronym for Institut für Arbeitsmarkt- und Berufsforschung, which is the research institute of the Federal Labour Office in Germany. 
The employer side of our data set is given by the "IAB Establishment Panel", a random sample of establishments from the comprehensive IAB Establishment Register drawn according to the principle of optimal stratification. The stratification cells are defined by ten classes for the size of the establishment and by 16 economic sectors. This selection process means that the selection probability of an establishment increases with its size. Every year since 1993 (1996) the IAB Establishment Panel has surveyed the same establishments from all branches and different size categories in western (eastern) Germany. In order to correct for panel mortality, exits and newly founded establishments, the panel is augmented regularly. The questionnaire covers a wide variety of questions which can be used for our analysis, such as information on the legal form, the profit situation and the location of the establishment, the state of production technology and on bargaining coverage. Data are collected in personal interviews with the owners or senior managers of the establishments by professional interviewers.

In 1997 a representative sample of establishments that reported under a new firm-identification-number in the employment statistics was drawn and integrated into the IAB Establishment Panel. From this sample 826 newly founded establishments can be used in our analysis, 368 of which can be traced every year until 2001 (although not all of these establishments provide information on all variables in every year). Each of these newly founded establishments hired its first employee between 1 July, 1995 and 30 June, 1996. Our sample was restricted to establishments that had less than 200 employees in $1997^{5}$ and that were in private ownership of one or more founders but were not owned by other firms, so there are no derivative foundations. The development of these newly founded establishments is contrasted with 5897 incumbent establishments from the private sector that had already existed in 1996 and had employed at least one person in 1997. Of these establishments 3207 could be traced in every year until 2001, the last year for which information from the employees' and employers' side is available.

5 Details regarding the IAB Establishment Panel (including information on the questionnaires and how to access the data) are given in Kölling (2000).

6 There is only one newly founded firm that was larger, on average the start-ups had five employees. 
In our empirical analysis we predominantly make use of the data from the IAB Establishment Panel, thus more or less taking an employers' perspective. In addition, exact data on the composition of the workforce and the number of employees as well as on the amount of wages and salaries paid in the establishment are supplied from the quasi-official German Employment Statistics via the IAB Establishment Register. The data are linked through a plant identifier that is available in both data sets. A short description of the data used with summary statistics can be found in an Appendix Table.

\section{Empirical analyses}

In order to empirically investigate the wage differential of firms founded in 1995/96 we estimate OLS regressions for the period 1997 to 2001, making use of stacked cross section models for each year as well as pooling the data. The dependent variable is the log of daily wages per (full-time equivalent) employee at establishment level. It is calculated by dividing the annual sum of all wages and salaries in an establishment by the sum of (calendar) days worked by all employees in this establishment. Since the number of days with part-time work is divided by 0.5 , we in fact calculate a sort of "full-time equivalents" of employment. Because of part-time work and fluctuations in employment our denominator is more precise than just using the number of employees at some point in time. The data stem from the "German Employment Statistics" and include all wages and salaries paid to each employee during a job up to the contribution assessment ceiling of the social security system. Since higher earnings are censored at this ceiling, wages in firms of high-income sectors are underreported. Although there is a certain downward bias in our wage variable, this should not systematically and seriously affect our results on the wage differential.

7 This contribution assessment ceiling is relatively high, amounting to $148 €$ in western and $124 €$ in eastern Germany per calendar-day in 2001. As the wage variable used is calculated at the establishment level whereas the contribution assessment ceiling refers to the individual level, there is no clear-cut truncation point which could be taken into account by choosing appropriate estimation methods (such as Tobit or truncated regression). At the other end of the spectrum, there was a small number of wages reported that were obviously too low and that probably reflected errors in the data base. We therefore omitted all incomes that were lower than twice the wages paid for so- 
The main interest of our analysis is on the wage behaviour of newly founded firms, which are represented by a dummy variable indicating whether an establishment hired its first employee between 1 July, 1995, and 30 June, 1996. The other independent variables used are standard in

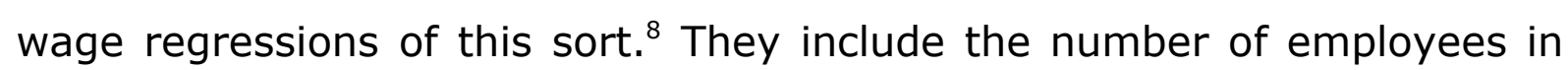
the establishment and its square (which are expected to exhibit the wellknown positive but decreasing establishment size effect on wages) as well as a dummy variable indicating whether the establishment is a branch plant or subsidiary (thus probably paying higher wages than similar independent firms). The structure of the workforce is represented by the employment shares of female, fixed-term and low-skilled employees (all of which are expected to receive lower wages) and of high-skilled and parttime employees. Although there is no such thing as a unionized establishment in Germany, it is necessary to control for the existence of sectoral or firm-level collective bargaining agreements, both of which are expected to raise wages. The ability to pay of an establishment is expressed by a dummy variable reflecting its subjective assessment of the ("very good or good") profit situation. We also take into account the export share of an establishment and its state of production technology, both of which should be positively correlated with wages. Further controls refer to the existence of wage subsidies and the legal form of the firm, although we have no clear-cut priors on the likely influence of these variables on the wages paid. We also include ten industry dummies and three dummies for the degree of urbanization at the location of the establishment. Since wages in western Germany are still substantially higher than in post-communist eastern Germany and since both labour markets still differ considerably, we include a dummy variable for western Germany in the aggregate analysis and also provide disaggregated estimates for western and eastern Germany.

called "mini jobs" (for which only flat-rate taxes are paid). This lower threshold was $21.18 €$ per day in 2001 in both parts of Germany.

8 Although we have a relatively rich data set, selection of control variables was limited by the fact that information on some potential explanatory variables was either never asked (this is the case for the capital stock and for fringe benefits) or was not available in all years of our observation period (e.g., existence of a works council and profit sharing). 
The results of the pooled estimations for the period 1997 to 2001 (which also include dummies for each year) are presented in Table 1. For Germany as a whole and for its western and eastern part alike, almost all coefficients estimated are highly significant and of the expected sign. While the impact of control variables needs not to be discussed in detail, the principal result is of course the negative effect of the newly founded establishment dummy on log wages. Over the entire period and the full sample, wages paid in newly founded establishments were 8.0 percent lower than in other firms. ${ }^{9}$ In western Germany, the average wage differential amounted to 12.8 percent, whereas it was just 6.1 percent in eastern Germany. This difference probably reflects the fact that wages in eastern Germany are generally about 20 percent lower, ceteris paribus (see the dummy variable for western Germany in column 1), and that new firms thus may have less scope for paying even lower wages there.

In addition to the average effects over the whole period shown in Table 1, Table 2 presents the results of cross section estimations for each single year. The models estimated are almost identical to those shown in Table 1,10 and by and large they are equally well determined. In order to economize on space, Table 2 just presents the estimated coefficients of the dummy variable for newly founded firms (full results are available from the authors on request). From the upper part of this table it can be seen that the point estimates of the wage differential tend to fall over time: While in 1997 wages were 13.4 percent lower in newly founded western German firms than in other firms, ceteris paribus, in 2001 the wage differential between these two groups of firms had narrowed to 7.7 percent (and lost significance over time). In eastern Germany, the wage differential fell from 6.3 percent in 1997 to 4.9 percent in 2001. Figure 1 displays (in intervals of two years) the development of the wage differential over time by presenting point estimates as well as 95 percent confidence intervals. Although the confidence intervals are quite large and

9 The percentage wage effect is calculated from the estimated coefficient $\beta$ as ( $e^{\beta}$ 1). 100 .

10 The only differences are that the year dummies are not included, of course, and that for all years except 1999 (where information is lacking) a dummy variable on the existence of overtime work is included which always proves to be significant. 
samples vary from year to year, there is some indication that (at least in western Germany) wage differentials narrow over time.

Table 1: Determinants of wages in German firms, 1997-2001

(OLS estimations; dependent variable: In wage; pooled data)

\begin{tabular}{|c|c|c|c|}
\hline Variable & Germany & Western Germany & Eastern Germany \\
\hline \multicolumn{4}{|c|}{$\frac{{ }^{2}}{4.2470^{* *}}$} \\
\hline & $(454.62)$ & (311.73) & $(354.06)$ \\
\hline $\begin{array}{l}\text { Newly founded establishment } \\
\text { (dummy: } 1=\text { yes) }\end{array}$ & $-0.0837^{* *}$ & $-0.1368^{* *}$ & $-0.0631^{\star *}$ \\
\hline $\begin{array}{l}\text { (dummy: } 1=\text { yes) } \\
\text { Establishment size }\end{array}$ & $(-11.46)$ & $(-8.62)$ & $(-8.17)$ \\
\hline $\begin{array}{l}\text { Establishment size } \\
\text { (number of employees) }\end{array}$ & $\begin{array}{c}0.00006^{* *} \\
(15.63)\end{array}$ & $\begin{array}{l}0.00004^{* *} \\
(9.48)\end{array}$ & $\begin{array}{c}0.0004^{* *} \\
(13.03)\end{array}$ \\
\hline Establishment size squared & $\begin{array}{l}-2.89 \mathrm{e}-09^{* *} \\
(-11.07)\end{array}$ & $-1.68 \mathrm{e}-09^{* *}$ & $-1.60 e-07^{* *}$ \\
\hline Branch plant/subsidiary & $0.0734^{* *}$ & $0.0483^{* *}$ & $0.0917^{* *}$ \\
\hline (dummy: 1 = yes) & $(15.15)$ & $(8.39)$ & $(11.53)$ \\
\hline Female employees & $-0.0030^{* *}$ & $-0.0030^{* *}$ & $-0.0029^{* *}$ \\
\hline (percentage) & $(-30.60)$ & $(-19.97)$ & $(-24.87)$ \\
\hline Part-time employees & $0.0025^{\star \star}$ & $0.0019^{* *}$ & $0.0035^{\star *}$ \\
\hline (percentage) & $(17.06)$ & $(8.64)$ & $(18.68)$ \\
\hline Fixed-term employees & $-0.0005^{* *}$ & 0.0006 & $-0.0011^{* *}$ \\
\hline $\begin{array}{l}\text { (percentage) } \\
\text { Hiah-skilled emplovees }\end{array}$ & $\begin{array}{l}(-3.41) \\
0.0063^{* *}\end{array}$ & $0.0069^{* *}$ & $\begin{array}{l}(-6.36) \\
00062 * *\end{array}$ \\
\hline $\begin{array}{l}\text { High-skilled employees } \\
\text { (percentage) }\end{array}$ & $\begin{array}{c}0.0063 n \\
(41.53)\end{array}$ & $(23.14)$ & $(35.01)$ \\
\hline Low-skilled employees & $-0.0010^{* *}$ & $-0.0019^{* *}$ & -0.0001 \\
\hline (percentage) & $(-12.30)$ & $(-14.80)$ & $(-1.53)$ \\
\hline Covered by sectoral collective & $0.1059^{* *}$ & $0.0908^{* *}$ & $0.0977^{* *}$ \\
\hline agreement (dummy: $1=$ yes) & $(23.32)$ & $(11.89)$ & (17.63) \\
\hline Covered by firm-level collective & $0.0805^{\star *}$ & $0.1016^{* *}$ & $0.0573^{* *}$ \\
\hline agreement (dummy: $1=$ yes) & $(13.06)$ & $(9.66)$ & $(7.80)$ \\
\hline Firm receives wage subsidies & $-0.0268^{* *}$ & $0.0250^{* *}$ & $-0.0560^{* *}$ \\
\hline (dummy: 1 = yes) & $\begin{array}{c}(-7.20) \\
0.0439^{* *}\end{array}$ & $\begin{array}{c}(4.45) \\
0.0327^{* *}\end{array}$ & $(-11.86)$ \\
\hline $\begin{array}{l}\text { Profit situation } \\
\text { (dummy: } 1 \text { = very good/good) }\end{array}$ & $\begin{array}{c}0.0439^{* *} \\
(11.44)\end{array}$ & $\begin{array}{l}0.0327^{* \star} \\
(5.80)\end{array}$ & $\begin{array}{c}0.0545^{\star *} \\
(10.74)\end{array}$ \\
\hline Export share & $0.0021^{* *}$ & $0.0019^{* *}$ & $0.0010^{* *}$ \\
\hline (percentage) & $(19.81)$ & $(15.87)$ & $(5.05)$ \\
\hline Production technology & $0.0517^{* *}$ & $0.0577^{* *}$ & $0.0414^{* *}$ \\
\hline (dummy: 1 = state of the art) & $(12.96)$ & $(9.72)$ & $(8.03)$ \\
\hline Legal form of the firm & $-0.1915^{* *}$ & $-0.1963^{* *}$ & $-0.1705^{* *}$ \\
\hline (dummy: 1 = family-owned firm) & $(-42.71)$ & $(-28.81)$ & $(-28.69)$ \\
\hline Year 1998 & $0.0161^{* *}$ & 0.0096 & $0.0197^{* *}$ \\
\hline (dummy) & $(3.13)$ & $(1.26)$ & $(2.90)$ \\
\hline Year 1999 & $0.0393^{* *}$ & $0.0326^{* *}$ & $0.0420^{* *}$ \\
\hline (dummy) & $(7.39)$ & $(4.15)$ & $(6.02)$ \\
\hline Year 2000 & $0.0478^{* *}$ & $0.0424^{* *}$ & $0.0507^{* *}$ \\
\hline (dummy) & $(8.78)$ & $(5.23)$ & (7.21) \\
\hline Year 2001 & $0.0696^{* *}$ & $0.0547^{* *}$ & $0.0794^{* *}$ \\
\hline (dummy) & $(11.94)$ & $(6.32)$ & (10.59) \\
\hline Western Germany & $0.2365^{\star *}$ & -- & -- \\
\hline (dummy: 1 = yes) & $(54.70)$ & & \\
\hline Industry dummies & yes $^{* *}$ & yes $^{* *}$ & yes $^{* *}$ \\
\hline Urbanization dummies & yes $^{* *}$ & yes $^{* *}$ & yes $^{* *}$ \\
\hline $\mathrm{n}$ & 20177 & 9721 & 10456 \\
\hline$R^{2}$ & 0.5966 & 0.5321 & 0.5295 \\
\hline
\end{tabular}

NOTE: Heteroscedastic-consistent t-values in parentheses, ${ }^{* *} /{ }^{*}$ denote statistical significance at the 0.01 and 0.05 levels, respectively.

SOURCE: IAB Establishment Panel. 
Figure 1: Wage differentials of newly founded firms over time

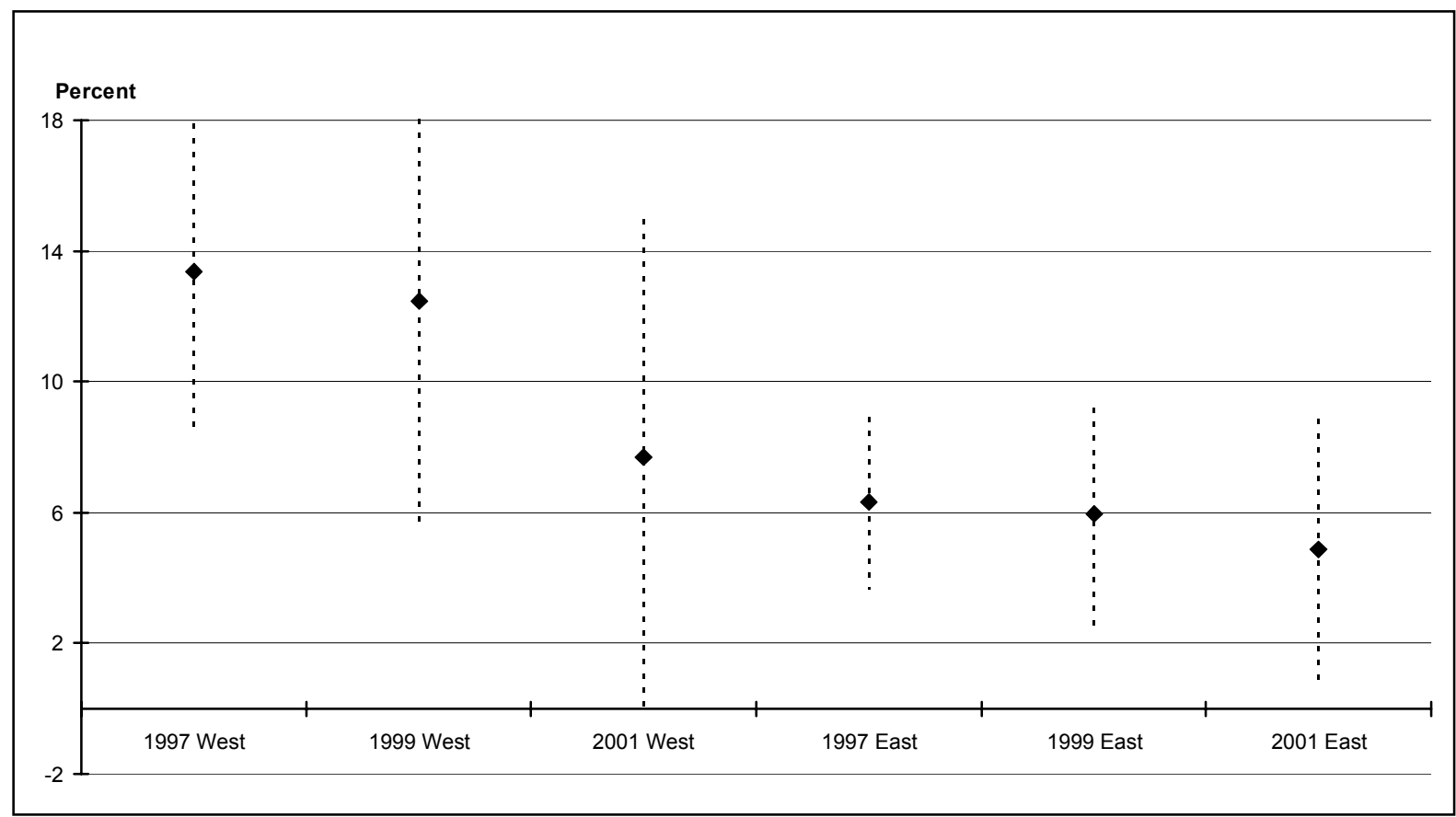

Point estimates from Table 2 and 95 percent confidence intervals

These estimates, however, might be biased in various ways due to the failure (or non-reporting) of newly founded and other firms in the panel. On the one hand, those newly founded firms that paid higher wages (i.e. had a smaller wage differential in 1997) may not have survived until 2001 due to excessive labour costs. On the other, the survivors should be those with the best business models, the most favourable economic prospects and the highest ability to pay throughout (i.e. those with higher wage differentials already in 1997). In addition, the rest of the firms in the sample also changed from year to year due to panel attrition. Since the number of newly founded (of all) establishments fell from 667 (5611) in the 1997 regression for Germany to 239 (2517) in 2001, it seems to make sense to pay a closer look to these surviving establishments in order to better identify the development of the wage differential over time.

The lower part of Table 2 presents the results of estimations for a balanced panel of 2517 firms that survived until 2001. It can be seen that in most years the estimated coefficients are in the same range as the estimates for all establishments and do not seem to differ systematically. 11

\footnotetext{
${ }^{11}$ We also tested this by including a dummy variable for surviving establishments and an
} interaction term of surviving and newly founded firms in the regressions on which the 
However, the significance levels of these coefficients are much lower (in particular in western Germany) which might reflect the fact that standard errors increase when the number of observations is reduced. From these results we may still conclude (albeit with less confidence) that newly founded firms tend to pay lower wages than incumbent ones and that this wages differential seems to narrow (or even disappear) over time.

Table 2: Wage differentials of newly founded firms over time (coefficients of OLS estimations similar to Table 1)

\begin{tabular}{|l|l|l|l|l|l|}
\hline All establishments & \multicolumn{1}{|c|}{1997} & \multicolumn{1}{c|}{1998} & \multicolumn{1}{c|}{1999} & \multicolumn{1}{|c|}{2000} & \multicolumn{1}{c|}{2001} \\
\hline Germany & $-0.0890^{* *}$ & $-0.0720^{* *}$ & $-0.0779^{* *}$ & $-0.0858^{* *}$ & $-0.0541^{* *}$ \\
Western Germany & $(-6.79)$ & $(-4.64)$ & $(-4.51)$ & $(-4.38)$ & $(-2.70)$ \\
& $-0.1435^{* *}$ & $-0.1259^{* *}$ & $-0.1333^{* *}$ & $-0.0976^{*}$ & -0.0799 \\
Eastern Germany & $(-5.30)$ & $(-3.92)$ & $(-3.45)$ & $(-2.05)$ & $(-1.92)$ \\
& $-0.0651^{* *}$ & $-0.0547^{* *}$ & $-0.0602^{* *}$ & $-0.0782^{* *}$ & $-0.0499^{*}$ \\
\hline Survivors only & $(-4.59)$ & $(-3.20)$ & $(-3.27)$ & $(-4.15)$ & $(-2.30)$ \\
\hline Germany & 1997 & 1998 & 1999 & 2000 & 2001 \\
& $-0.0866^{* *}$ & $-0.0676^{* *}$ & $-0.0769^{* *}$ & $-0.0726^{* *}$ & $-0.0592^{* *}$ \\
Western Germany & $(-3.68)$ & $(-2.92)$ & $(-3.25)$ & $(-3.11)$ & $(-2.75)$ \\
& -0.1045 & $-0.1263^{*}$ & -0.1086 & -0.0889 & -0.0862 \\
Eastern Germany & $(-1.88)$ & $(-2.46)$ & $(-1.87)$ & $(-1.61)$ & $(-1.84)$ \\
& $-0.0733^{* *}$ & -0.0358 & $-0.0566^{*}$ & $-0.0573^{*}$ & -0.0412 \\
\hline
\end{tabular}

NOTE: Heteroscedastic-consistent t-values in parentheses, ${ }^{* *} /{ }^{*}$ denote statistical significance at the 0.01 and 0.05 levels, respectively. In 2001, the number of observations and the estimated coefficients are not exactly identical between all establishments and survivors since the latter group includes only those establishments for which we have information in each single year (balanced panel).

SOURCE: IAB Establishment Panel.

As a further test of robustness of our results we restricted the sample to small and medium-sized establishments that had less than 200 employees in our starting year 1997 (as noted above, all newly founded firms fall into this group). Although the estimations above with the full sample of all establishments included plant size as a determinant of wages, experience suggests that this may not suffice to capture all the effects of different es-

upper part of Table 2 is based. Since both variables did not prove to be statistically significant we may conclude that the wages paid in surviving firms do not differ significantly from those in other firms. This confirms the finding of Audretsch et al. (2001: 818 ) that "differentials in employee compensation are far more attributable to firm size than to whether the firm ultimately survives or fails." 
tablishment sizes of newly founded and incumbent firms. Therefore it might be helpful to compare groups of firms that are more similar with respect to establishment size.

Table 3 presents the results of the estimations with the restricted sample, again concentrating on the coefficients of the dummy variable for newly founded firms. The pooled estimations for 1997 to 2001 shown in the first column confirm the significant negative effect of this dummy on log wages found in the unrestricted sample. It is interesting to see, however, that the wage differential is smaller once large incumbent firms are left out. In the sub-sample of establishments with less than 200 employees, wages paid in newly founded establishments were 5.7 percent lower than in similar incumbent firms in Germany (with the average wage differential amounting to 8.5 percent in western and 5.6 percent in eastern Germany).

Table 3: Wage differentials of newly founded firms: sample restricted to establishments with less than 200 employees in 1997 (coefficients of OLS estimations similar to Table 1)

\begin{tabular}{|l|l|l|l|l|l|l|}
\hline $\begin{array}{l}\text { Establishments } \\
<200 \text { employees }\end{array}$ & $\begin{array}{l}1997-2001 \\
\text { (pooled) }\end{array}$ & \multicolumn{1}{|c|}{1997} & \multicolumn{1}{c|}{1998} & \multicolumn{1}{c|}{1999} & 2000 & 2001 \\
\hline Germany & $-0.0589^{* *}$ & $-0.0644^{* *}$ & $-0.0509^{* *}$ & $-0.0565^{* *}$ & $-0.0667^{* *}$ & -0.0340 \\
Western Germany & $(-8.08)$ & $(-4.90)$ & $(-3.27)$ & $(-3.27)$ & $(-3.43)$ & $(-1.71)$ \\
& $-0.0892^{* *}$ & $-0.0992^{* *}$ & $-0.0883^{* *}$ & $-0.0864^{*}$ & -0.0576 & -0.0394 \\
Eastern Germany & $(-5.62)$ & $(-3.63)$ & $(-2.72)$ & $(-2.24)$ & $(-1.21)$ & $(-0.95)$ \\
& $-0.0571^{* *}$ & $-0.0580^{* *}$ & $-0.0472^{* *}$ & $-0.0603^{* *}$ & $-0.0721^{* *}$ & -0.0401 \\
& $(-7.37)$ & $(-4.07)$ & $(-2.75)$ & $(-3.25)$ & $(-3.80)$ & $(-1.84)$ \\
\hline
\end{tabular}

NOTE: Heteroscedastic-consistent t-values in parentheses, ${ }^{* *} /{ }^{*}$ denote statistical significance at the 0.01 and 0.05 levels, respectively.

SOURCE: IAB Establishment Panel.

The cross section estimations for each year presented in the following columns of Table 3 show again that the point estimates of the wage differential tend to fall and become less significant over time. In the sub-sample of establishments with less than 200 employees, after four years the wage differential between newly founded and incumbent firms in western Germany has become statistically insignificant. In eastern Germany, this process takes five years. Put differently, this result implies that - at least concerning wages - it takes a new firm four to five years to become an incumbent firm. 


\section{Concluding remarks}

Our empirical analysis of a cohort of newly founded and other establishments in Germany from 1997 to 2001 has indicated that start-ups tend to pay lower wages, ceteris paribus. This negative wage differential is substantially smaller in eastern Germany where the wage floor is lower and where firms may have less scope for paying wages that are still lower. The wage differential was shown to decline over time as the newly founded firms become more mature. In the fifth (and last) year of our observation period the wage differential had become insignificant in quite a few of the alternative samples investigated, but it needs additional waves of our panel data set before we can safely conclude whether and when this differential disappears completely.

The reasons for the negative wage differential found are difficult to identify and disentangle. One reason could be that newly founded firms rely more on workers (of a given quality) that are recruited from the pool of unemployed or from out of the labour force and that are less expensive, but currently we do not have reliable information yet on the origin of employees in an establishment. Lower wages might also be paid if the establishment compensates for this disadvantage by additional fringe benefits or by increased use of employee participation schemes. However, higher monetary fringe benefits should have been picked up by our comprehensive wage variable, and our newly founded firms are not more likely to use employee participation schemes than other firms. ${ }^{12}$ Finally, ability to pay may play a role, and although we have included a crude dummy variable for the profit situation of the establishment (plus indicators of the state of technology and of the share of exports), these variables may capture ability to pay imperfectly, so that the dummy variable for newly founded firms could pick up part of this effect.

12 For the year 1998, the first year with corresponding information, a simple probit estimation was conducted with the existence of an employee participation scheme as the dependent variable and establishment size (plus its square), industry dummies and the dummy for newly founded establishments as explanatory variables. Neither for Germany nor for its western and eastern parts we found a significant influence of newly founded establishments on the probability that an employee participation scheme exists. 
In addition to overcoming these data problems, a promising avenue for future research on the firm age and wage nexus would be to investigate how the wage of a given employee changes when he or she moves from an incumbent to a newly founded establishment. An equally interesting question is how the income of the owner of a firm evolves over time, compared to that of his employees and to his (fictional) income if he had stayed employed instead of becoming self-employed. Wages and income are still a largely neglected source of information on the performance of new firms and on the quality of the jobs provided that should be tapped more intensively. 


\section{Appendix}

Table: Summary statistics

(pooled data for 1997-2001, $\mathrm{n}=20177$ )

\begin{tabular}{|c|c|c|c|c|}
\hline Variable & Mean & Std. Dev. & Min & Max \\
\hline $\begin{array}{l}\text { Log of daily wage per employee } \\
\text { (full-time equivalents, in Euros) }\end{array}$ & 4.10 & 0.40 & 2.43 & 5.51 \\
\hline $\begin{array}{l}\text { Newly founded establishment } \\
\text { (dummy: } 1 \text { = yes) }\end{array}$ & 0.11 & 0.31 & 0 & 1 \\
\hline $\begin{array}{l}\text { Establishment size (number of } \\
\text { employees, full-time equivalents) }\end{array}$ & 184.17 & 740.24 & 0.01 & 25145.42 \\
\hline $\begin{array}{l}\text { Branch plant/subsidiary } \\
\text { (dummy: } 1 \text { = yes) }\end{array}$ & 0.14 & 0.35 & 0 & 1 \\
\hline $\begin{array}{l}\text { Female employees } \\
\text { (percentage) }\end{array}$ & 36.99 & 32.88 & 0 & 100 \\
\hline $\begin{array}{l}\text { Part-time employees } \\
\text { (percentage) }\end{array}$ & 9.56 & 21.11 & 0 & 100 \\
\hline $\begin{array}{l}\text { Fixed-term employees } \\
\text { (percentage) }\end{array}$ & 3.51 & 10.54 & 0 & 100 \\
\hline $\begin{array}{l}\text { High-skilled employees } \\
\text { (percentage) }\end{array}$ & 6.14 & 13.80 & 0 & 100 \\
\hline $\begin{array}{l}\text { Low-skilled employees } \\
\text { (percentage) }\end{array}$ & 20.18 & 29.59 & 0 & 100 \\
\hline $\begin{array}{l}\text { Covered by sectoral collective } \\
\text { agreement (dummy: } 1 \text { = yes) }\end{array}$ & 0.50 & 0.50 & 0 & 1 \\
\hline $\begin{array}{l}\text { Covered by firm-level collective } \\
\text { agreement (dummy: } 1 \text { = yes) }\end{array}$ & 0.10 & 0.30 & 0 & 1 \\
\hline $\begin{array}{l}\text { Firm receives wage subsidies } \\
\text { (dummy: } 1 \text { = yes) }\end{array}$ & 0.28 & 0.45 & 0 & 1 \\
\hline $\begin{array}{l}\text { Profit situation } \\
\text { (dummy: } 1 \text { = very good/good) }\end{array}$ & 0.31 & 0.46 & 0 & 1 \\
\hline $\begin{array}{l}\text { Export share } \\
\text { (percentage) }\end{array}$ & 6.76 & 17.45 & 0 & 100 \\
\hline $\begin{array}{l}\text { Production technology } \\
\text { (dummy: } 1 \text { = state of the art) }\end{array}$ & 0.69 & 0.46 & 0 & 1 \\
\hline $\begin{array}{l}\text { Legal form of the firm } \\
\text { (dummy: } 1 \text { = family-owned firm) }\end{array}$ & 0.41 & 0.49 & 0 & 1 \\
\hline $\begin{array}{l}\text { Western Germany } \\
\text { (dummy: } 1=\text { yes) }\end{array}$ & 0.48 & 0.50 & 0 & 1 \\
\hline
\end{tabular}

SOURCE: IAB Establishment Panel.

\section{References}

Almus, Matthias, 2002, Wachstumsdeterminanten junger Unternehmen, Baden-Baden: Nomos.

Audretsch, David B., George van Leeuwen, Bert Menkveld and Roy Thurik, 2001, 'Market dynamics in the Netherlands: Competition policy and the role of small firms', International Journal of Industrial Organization 19, 795-821. 
Brixy, Udo and Susanne Kohaut, 1999, 'Employment Growth Determinants in New Firms in Eastern Germany', Small Business Economics 13, 155170 .

Brown, Charles, James Hamilton and James L. Medoff, 1990, Employers Large and Small, Cambridge, Mass., London: Harvard University Press.

Brown, Charles and James L. Medoff, 2003, 'Firm Age and Wages', Journal of Labor Economics 21, 677-697.

Brüderl, Josef, Peter Preisendörfer and Rolf Ziegler, 1996, Der Erfolg neugegründeter Betriebe, Berlin: Duncker \& Humblot.

Dunne, Timothy, Mark J. Roberts and Larry Samuelson, 1989, 'The growth and failure of U.S. manufacturing plants', Quarterly Journal of Economics 104, 671-698.

Heyman, Frederik, 2004, 'The Employer Age-Wage Effect: Evidence from Matched Employer-Employee Data', FIEF Working Paper No. 193, Trade Union Institute for Economic Research (FIEF), Stockholm.

Kölling, Arnd, 2000, 'The IAB-Establishment Panel', Schmollers Jahrbuch, Journal of Applied Social Science Studies 120, 291-300.

Kölling, Arnd, Claus Schnabel and Joachim Wagner, 2002, Establishment Age and Wages: Evidence from German Linked Employer-Employee Data, IZA Discussion Paper No. 679, Institute for the Study of Labor (IZA), Bonn.

Lewin, David and Daniel J.B. Mitchell, 1995, Human Resource Management: An Economic Approach, $2^{\text {nd }}$ ed., Cincinnati: South-Western College Publishing.

Oi, Walter Y. and Todd Idson, 1999, 'Firm Size and Wages', in Orley Ashenfelter and David Card (eds.), Handbook of Labor Economics, vol. 3, Amsterdam: Elsevier Science, pp. 2165-2214.

Schmidt, Elke Maria, 1995, Betriebsgröße, Beschäftigtenentwicklung und Entlohnung, Frankfurt, New York: Campus.

Storey, David J., 1994, Understanding the Small Business Sector, London, New York: Routledge.

Wagner, Joachim, 1994, 'The post-entry performance of new small firms in German manufacturing industries', Journal of Industrial Economics 42, 141-154.

Wagner, Joachim, 1997, 'Firm Size and Job Quality: A Survey of the Evidence from Germany', Small Business Economics 9, 411-425. 


\section{In dieser Reihe sind zuletzt erschienen: Recently published:}

$1 \quad$ Bauer, Th. K.,

Dismissal Protection and Worker Flows in

$7 / 2004$ Bender, St., Bonin, $\mathrm{H}$.

2 Achatz, J., Gartner, H., Glück, T.

Small Establishments

$7 / 2004$

Bonus oder Bias? Mechanismen ge-

schlechtsspezifischer Entlohnung

3 Andrews, M., Practical estimation methods for linked em-

$8 / 2004$ Schank, Th., Upward, R.

ployer-employee data 


\section{IABDiscussionPaper}

No. 4 / 2004

\section{Herausgeber}

Institut für Arbeitsmarkt- und Berufsforschung der Bundesagentur für Arbeit

Weddigenstr. 20-22

D-90478 Nürnberg

\section{Redaktion}

Regina Stoll, Jutta Palm-Nowak

Technische Herstellung Jutta Sebald

\section{Rechte}

Nachdruck - auch auszugsweise - nur mit Genehmigung des IAB gestattet

\section{Bezugsmöglichkeit}

Volltext-Download dieses DiscussionPaper

unter:

http://doku.iab.de/discussionpapers/2004/dp0404.pdf

\section{IAB im Internet}

http://www.iab.de

\section{Rückfragen zum Inhalt an}

Susanne Kohaut, Tel. 0911/179-3253,

oder e-Mail: susanne.kohaut@iab.de 